\title{
Urinary tract infections in patients with type 2 diabetes mellitus: review of prevalence, diagnosis, and management
}

This article was published in the following Dove Press journal:

Diabetes, Metabolic Syndrome and Obesity: Targets and Therapy

26 February 2015

Number of times this article has been viewed

\author{
Orna Nitzan ${ }^{1-3}$ \\ Mazen Elias ${ }^{2,4}$ \\ Bibiana Chazan ${ }^{1,2}$ \\ Walid Saliba ${ }^{2,4}$ \\ 'Infectious Disease Unit, Ha'emek \\ Medical Center, Afula, Israel; ${ }^{2}$ Bruce \\ Rappaport Faculty of Medicine, \\ Technion-Israel Institute of \\ Technology, Haifa, Israel; ${ }^{3}$ Infectious \\ Disease Unit, Padeh-Poriya Medical \\ Center, ${ }^{4}$ Department of Internal \\ Medicine C, Ha'emek Medical Center, \\ Afula, Israel
}

\begin{abstract}
Urinary tract infections are more common, more severe, and carry worse outcomes in patients with type 2 diabetes mellitus. They are also more often caused by resistant pathogens. Various impairments in the immune system, poor metabolic control, and incomplete bladder emptying due to autonomic neuropathy may all contribute to the enhanced risk of urinary tract infections in these patients. The new anti-diabetic sodium glucose cotransporter 2 inhibitors have not been found to significantly increase the risk of symptomatic urinary tract infections. Symptoms of urinary tract infection are similar to patients without diabetes, though some patients with diabetic neuropathy may have altered clinical signs. Treatment depends on several factors, including: presence of symptoms, severity of systemic symptoms, if infection is localized in the bladder or also involves the kidney, presence of urologic abnormalities, accompanying metabolic alterations, and renal function. There is no indication to treat diabetic patients with asymptomatic bacteriuria. Further studies are needed to improve the treatment of patients with type 2 diabetes and urinary tract infections.
\end{abstract}

Keywords: diabetes mellitus, diagnosis, management, prevalence, urinary tract infection

\section{Introduction}

Type 2 diabetes mellitus is a heterogeneous group of disorders characterized by variable degrees of insulin resistance, impaired insulin secretion, and increased glucose production. Patients with type 2 diabetes mellitus are at increased risk of infections, with the urinary tract being the most frequent infection site. ${ }^{1-4}$ Various impairments in the immune system, ${ }^{5,6}$ in addition to poor metabolic control of diabetes, ${ }^{7,8}$ and incomplete bladder emptying due to autonomic neuropathy ${ }^{9,10}$ may all contribute in the pathogenesis of urinary tract infections (UTI) in diabetic patients. Factors that were found to enhance the risk for UTI in diabetics include age, metabolic control, and long term complications, primarily diabetic nephropathy and cystopathy. ${ }^{11}$

The spectrum of UTI in these patients ranges from asymptomatic bacteriuria (ASB) to lower UTI (cystitis), pyelonephritis, and severe urosepsis. Serious complications of UTI, such as emphysematous cystitis and pyelonephritis, renal abscesses and renal papillary necrosis, are all encountered more frequently in type 2 diabetes than in the general population. ${ }^{12,13}$ Type 2 diabetes is not only a risk factor for community-acquired UTI but also for health care-associated UTI, ${ }^{14}$ catheter-associated UTI, ${ }^{15}$ and post-renal transplant-recurrent UTI. ${ }^{16}$ In addition, these patients are more prone to have resistant pathogens as the cause of their UTI, including extended-spectrum $\beta$-lactamase-positive Enterobacteriaceae, ${ }^{17}$ fluoroquinolone-resistant uropathogens, ${ }^{18}$ carbapenem-resistant Enterobacteriaceae, ${ }^{19}$ and vancomycin-resistant Enterococci. ${ }^{20}$ Type 2 diabetes is also
Correspondence: Walid Saliba Department of Internal Medicine C, Ha'emek Medical Center,

Afula I8I0I, Israel

$\mathrm{Tel}+97246495132$

Fax +972 46495134

Email saliba_wa@clalit.org.il 
a risk factor for fungal UTI, mostly caused by Candida $^{21}$ Diabetes is also associated with worse outcomes of UTI, including longer hospitalizations and increased mortality.

The increased risk of UTI among diabetic patients, coupled with the increase in the incidence of type 2 diabetes mellitus worldwide in recent years, may impose a substantial burden on medical costs. ${ }^{22}$ In addition, the high rates of antibiotic prescription, including broad-spectrum antibiotics, for UTI in these patients may further induce the development of antibiotic-resistant urinary pathogens. ${ }^{23}$

In this review, we will focus on the various types of UTI in this population, their frequency, risk factors, diagnosis, prognosis, and when and what treatment should be administered.

\section{The risk of UTI in type 2 diabetes mellitus}

All types of UTI are more frequent in patients with type 2 diabetes. Various studies have reported the overall incidence of UTI among these patients. An observational study of all patients with type 2 diabetes in the UK general practice research database found that the incidence rate of UTI was 46.9 per 1,000 person-years among diabetic patients and 29.9 for patients without diabetes. ${ }^{24}$ Women with previously diagnosed diabetes had a higher risk of UTI than those with recently diagnosed diabetes (within 6 months) (91.9/1,000 person-years; 95\% confidence interval [CI] 84.3-99.4, vs 70.5/1,000 person-years; 95\% CI 68.2-72.8). ${ }^{24}$ A cohort study of over 6,000 patients enrolled in ten clinical trials found an incidence rate of 91.5 per 1,000 personyears in women and 28 per 1,000 person-years in men, and a cumulative incidence of $2 \%$ during 6 months. ${ }^{25}$ A recent American study performed on a health service data base with more than 70,000 patients with type 2 diabetes found that $8.2 \%$ were diagnosed with UTI during 1 year $(12.9 \%$ of women and $3.9 \%$ of men, with incidence increasing with age). ${ }^{22}$ Another American database study from 2014 found that a UTI diagnosis was more common in men and women with diabetes than in those without diabetes $(9.4 \%$ vs $5.7 \%$, respectively) among 89,790 matched pairs of patients with and without type 2 diabetes mellitus. ${ }^{26}$

$\mathrm{ASB}$ is more prevalent in women, due to a short urethra that is in proximity to the warm, moist, vulvar, and perianal areas that are colonized with enteric bacteria. ASB increases with age, and is also associated with urinary tract abnormalities or foreign bodies (urethral catheters, stents, etc). ${ }^{27,28}$ Many studies have reported an increased prevalence of ASB in diabetic patients, with estimates ranging from $8 \%-26 \%{ }^{7,8,29,30}$
A meta- analysis of 22 studies, published in 2011, found a point prevalence of $12.2 \%$ of ASB among diabetic patients versus $4.5 \%$ in healthy control subjects. ${ }^{31}$ The point prevalence of ASB was higher both in women and men, was higher in patients with a longer duration of diabetes, and was not associated with glycemic status, as evaluated by glycosylated hemoglobin $\mathrm{A}_{1 \mathrm{c}}\left(\mathrm{HbA}_{1 \mathrm{c}}\right) \cdot{ }^{31} \mathrm{~A}$ recent prospective study of inpatients at an Indian hospital found a 30\% prevalence rate of ASB among diabetic patients. ${ }^{32}$

Pyelonephritis was found to be 4.1 times more frequent in pre-menopausal diabetic women than in women without diabetes in a case control study of a Washington State health group. ${ }^{33}$ In a Canadian study, diabetic women (type 1 and 2, identified by receipt of oral hypoglycemic or insulin therapy) were 6-15 times more frequently hospitalized (depending upon age group) for acute pyelonephritis than non-diabetic women, and diabetic men were hospitalized 3.4-17 times more than non-diabetic men. ${ }^{34}$ A Danish study reported patients with diabetes mellitus were 3 times more likely to be hospitalized with pyelonephritis, as compared to subjects without diabetes. ${ }^{35}$

In men, risk of acute bacterial prostatitis, prostatic abscess, progression to chronic prostatitis, and infections following prostatic manipulations, such as trans-rectal prostate biopsy, is increased in patients with diabetes mellitus..$^{36,37}$

\section{Pathogenesis, risk factors, and pathogens of UTI in patients with diabetes \\ Pathogenesis and risk factors}

Multiple potential mechanisms unique to diabetes may contribute to the increased risk of UTI in diabetic patients. ${ }^{38}$ Higher glucose concentrations in urine may promote the growth of pathogenic bacteria. ${ }^{8,39}$ However, several studies did not find an association between $\mathrm{HbA}_{1 \mathrm{c}}$ level, which serves as a proxy for glycosuria, and risk of UTI among diabetic patients; also, sodium glucose cotransporter 2 inhibitors, which increase glycosuria, were not found to increase the rate of UTI. ${ }^{3,40}$ High renal parenchymal glucose levels create a favorable environment for the growth and multiplication of microorganisms, which might be one of the precipitating factors of pyelonephritis and renal complications such as emphysematous pyelonephritis. ${ }^{30,41}$ Various impairments in the immune system, including humoral, cellular, and innate immunity may contribute in the pathogenesis of UTI in diabetic patients. ${ }^{5,6,42}$ Lower urinary interleukin-6 and -8 levels were found in patients with diabetes with ASB, compared to those without diabetes with ASB. ${ }^{41}$ Autonomic neuropathy 
involving the genitourinary tract results in dysfunctional voiding and urinary retention, decreasing physical bacterial clearance through micturition, thereby facilitating bacterial growth. ${ }^{9,10,43}$ Bladder dysfunction occurs in $26 \%-85 \%$ of diabetic women, depending on age extent of neuropathy and duration of diabetic disease, ${ }^{44}$ and thus should be considered in all diabetic patients with UTI.

A paper from Saudi Arabia found the following factors to be associated with an increased risk of UTI among patients with diabetes: female sex (relative risk [RR] 6.1), hypertension (RR 1.2), insulin therapy (RR 1.4), body mass index $(\mathrm{BMI})>30 \mathrm{~kg} / \mathrm{m}^{2}$ (RR 1.72), and nephropathy (RR 1.42). ${ }^{45}$ The release of new anti-diabetic sodium glucose cotransporter 2 inhibitors, which increase glycosuria, caused concern of a possible increase in UTIs, ${ }^{46}$ though a recent meta-analysis found similar incidences of UTI in patients treated with canagliflozin as compared with control groups. ${ }^{47}$ Dapagliflozin was associated with a slight increase in UTI (4.8\% vs 3.7\%), though no increase in pyelonephritis was found. ${ }^{48}$

\section{Pathogens}

The most common pathogens isolated from urine of diabetic patients with UTI are Escherichia coli, other Enterobacteriaceae such as Klebsiella spp., Proteus spp., Enterobacter spp., and Enterococci. ${ }^{49}$ Patients with diabetes are more prone to have resistant pathogens as the cause of their UTI, including extended-spectrum $\beta$-lactamase-positive Enterobacteriaceae, ${ }^{17,50}$ fluoroquinolone-resistant uropathogens, ${ }^{18}$ carbapenemresistant Enterobacteriaceae, ${ }^{19}$ and vancomycin-resistant Enterococci. ${ }^{20}$ This might be due to several factors, including multiple courses of antibiotic therapy that are administered to these patients, frequently for asymptomatic or only mildly symptomatic UTI, and increased incidence of hospitalacquired and catheter-associated UTI, which are both associated with resistant pathogens. Type 2 diabetes is also a risk factor for fungal $\mathrm{UTI}^{21}$

\section{Diagnosis}

The diagnosis of UTI should be suspected in any diabetic patient with symptoms consistent with UTI. These symptoms are: frequency, urgency, dysuria, and suprapubic pain for lower UTI; and costovertebral angle pain/tenderness, fever, and chills, with or without lower urinary tract symptoms for upper UTI. Diabetic patients are prone to have a more severe presentation of UTI, ${ }^{12}$ though some patients with diabetic neuropathy may have altered clinical signs. A recent multi-center study from South Korea of women with community-acquired acute pyelonephritis found that significantly fewer of the diabetic patients had flank pain, costovertebral angle tenderness, and symptoms of lower UTI as compared to non-diabetic women. ${ }^{51}$ Patients with type 2 diabetes and UTI might present with hypo- or hyperglycemia, non-ketotic hyperosmolar state, or even ketoacidosis, all of which prompt a rapid exclusion of infectious precipitating factors, including UTI ${ }^{8,52}$

Once the diagnosis of UTI is suspected, a midstream urine specimen should be examined for the presence of leukocytes, as pyuria is present in almost all cases of UTI. ${ }^{8,53}$ Pyuria can be detected either by microscopic examination (defined as $\geq 10$ leukocytes $/ \mathrm{mm}^{3}$ ), or by dipstick leukocyte esterase test (sensitivity of $75 \%-96 \%$ and specificity of $94 \%-98 \%$, as compared with microscopic examination, which is the gold standard).$^{54}$ An absence of pyuria on microscopic assessment can suggest colonization, instead of infection, when there is bacteriuria. ${ }^{54}$ Microscopic examination allows for visualizing bacteria in urine. A dipstick also tests for the presence of urinary nitrite. A positive test indicates the presence of bacteria in urine, while a negative test can be the product of low count bacteriuria or bacterial species that lack the ability to reduce nitrate to nitrite (mostly Gram-positive bacteria). ${ }^{55}$ Microscopic or macroscopic hematuria is sometimes present, and proteinuria is also a common finding. ${ }^{56}$

A urine culture should be obtained in all cases of suspected UTI in diabetic patients, prior to initiation of treatment. The only exceptions are cases of suspected acute cystitis in diabetic women who do not have long term complications of diabetes, including diabetic nephropathy, or any other complicating urologic abnormality. ${ }^{8}$ However, even in these cases, if empiric treatment fails or there is recurrence within 1 month of treatment, a culture should be obtained. The preferred method of obtaining a urine culture is from voided, clean-catch, midstream urine. ${ }^{56}$ When such a specimen cannot be collected, such as in patients with altered sensorium or neurologic/ urologic defects that hamper the ability to void, a culture may be obtained through a sterile urinary catheter inserted by strict aseptic technique, or by suprapubic aspiration. In patients with long-term indwelling catheters, the preferred method of obtaining a urine specimen for culture is replacing the catheter and collecting a specimen from the freshly placed catheter, due to formation of biofilm on the catheter. ${ }^{57,58}$

\section{The definition of a positive urine culture}

The definition of a positive urine culture depends on the presence of symptoms and the method of urinary specimen collection, as follows and as depicted in Figure 1. For the diagnosis of cystitis or pyelonephritis in women, a midstream urine count 


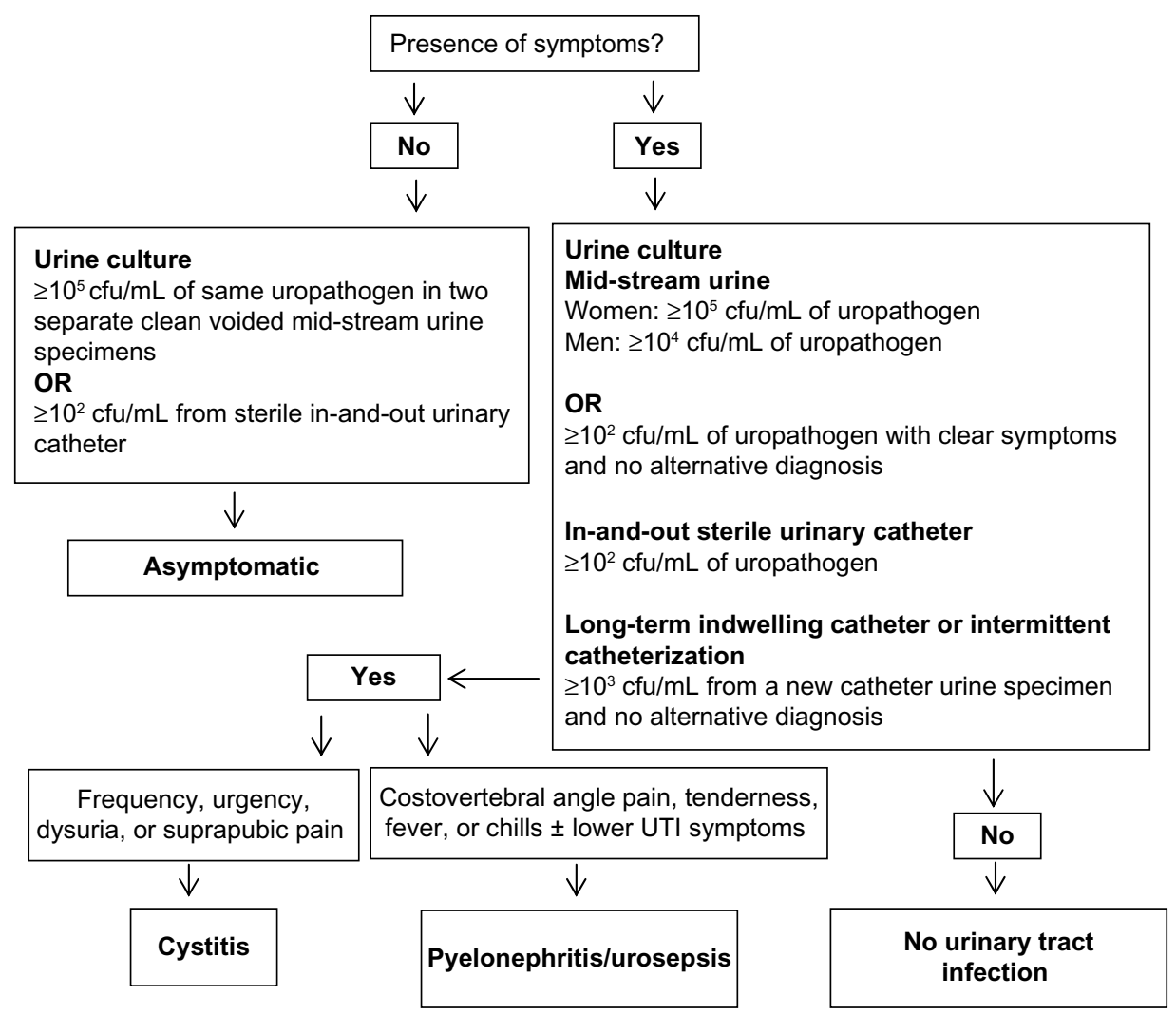

Figure I Flow chart for the diagnosis of urinary tract infection in patients with type 2 diabetes mellitus. Abbreviations: cfu, colony-forming units; UTI, urinary tract infection.

$\geq 10^{5} \mathrm{cfu} / \mathrm{mL}$ is considered diagnostic of UTI. ${ }^{59}$ However, in diabetic women with good metabolic control and without longterm complications who present with acute uncomplicated cystitis, quantitative counts $<10^{5}$ colony-forming units [cfu] $\mathrm{mL}$ are isolated from $20 \%-25 \%$ of premenopausal women and about $10 \%$ of postmenopausal women. ${ }^{8}$ Only $5 \%$ of patients with acute pyelonephritis have lower quantitative counts isolated. ${ }^{8}$ Lower bacterial counts are more often encountered in patients already on antimicrobials and are thought to result from impaired renal concentrating ability or diuresis, which limits the dwell time of urine in the bladder. ${ }^{8,60}$ Thus, in symptomatic women with pyuria and lower midstream urine counts ( $\geq 10^{2} \mathrm{cfu} / \mathrm{mL}$ ), a diagnosis of UTI should be suspected.

For the diagnosis of UTI in men, a midstream urine colony count of $\geq 10^{4} \mathrm{cfu} / \mathrm{mL}$ is indicative. However, when coliform bacteria (eg, E. coli) are isolated, lower colony counts might also represent significant bacteriuria. ${ }^{61}$

From an in-and-out catheter specimen, growth of $\geq 10^{2} \mathrm{cfu} / \mathrm{mL}$, in the presence of urinary symptoms, is diagnostic of UTI. ${ }^{62}$ In patients with long-term indwelling catheters or intermittent catheterization, growth of $\geq 10^{3} \mathrm{cfu} / \mathrm{mL}$ from a single new catheter urine specimen indicates UTI; in a midstream voided urine specimen from a patient whose urethral, suprapubic, or condom catheter that has been removed within the previous 48 hours, and has no other identified source of infection, similar numbers would also indicate UTI. ${ }^{57}$

The diagnosis of ASB can be made based on a growth of $\geq 10^{5} \mathrm{cfu} / \mathrm{mL}$ of the same uropathogen (up to two pathogens) in two consecutive clean voided mid-stream urine specimens, or $\geq 10^{2} \mathrm{cfu} / \mathrm{mL}$ in a specimen collected through a sterile in-and-out urinary catheter, in the absence of signs or symptoms of urinary infection. ${ }^{63}$ As many as $70 \%$ of diabetic women with ASB have accompanying pyuria. Thus, the presence of pyuria is not useful for differentiating between symptomatic or asymptomatic UTI. ${ }^{64}$

\section{Outcomes and complications Outcomes}

Patients with diabetes have worse outcomes of UTI than those without diabetes. ${ }^{13,65}$ Diabetes was found to be risk factor for early clinical failure after 72 hours of antibiotic treatment in women with community-onset acute pyelonephritis. ${ }^{66}$ Diabetes is also associated with longer hospitalization, bacteremia, azotemia, and septic shock in patients with UTI. ${ }^{12}$ Mortality from UTI is 5 times higher in patients with diabetes aged 65 and older, as compared to elderly control patients. ${ }^{12}$ 
Relapse and reinfection are also more common in diabetic patients $(7.1 \%$ and $15.9 \%$, respectively, vs $2.0 \%$ and $4.1 \%$, respectively, in women without diabetes) according to a Dutch study of diabetic women with UTI. ${ }^{67}$ Another study also found higher rates of recurrence of UTI in patients with type 2 diabetes of $1.6 \%$, vs $0.6 \%$ in non-diabetic patients. ${ }^{26}$

\section{Complications}

Over $90 \%$ of cases of emphysematous pyelonephritis ${ }^{41}$ and $67 \%$ of episodes of emphysematous cystitis ${ }^{68}$ occur in patients with diabetes mellitus. Renal and perinephric abscesses occur far more frequently in diabetic patients as well. ${ }^{13}$ Urosepsis and bacteremia are also more frequent in patients with diabetes. A Greek study from 2009 found that within a group of hospitalized elderly patients with acute pyelonephritis, $30.7 \%$ of patients with diabetes had bacteremia compared to $11 \%$ of patients without diabetes. ${ }^{12}$

\section{Management}

Treatment of UTI in patients with type 2 diabetes depends on several factors, including: presence of symptoms, if infection is localized in the bladder (lower UTI) or also involves the kidney (upper UTI), presence of urologic abnormalities, severity of systemic symptoms, accompanying metabolic alterations, and renal function. ${ }^{8}$ As a general rule, treatment of UTI in diabetic patients is similar to that of UTI in nondiabetic patients. Antibiotic choice should also be guided by local susceptibility patterns of uropathogens. Treatment should also involve correction of metabolic complications caused by the infectious process. First-line treatment options for various types of UTI are detailed in Table 1.

There is no indication to treat ASB in diabetic patients. ${ }^{69}$ Though earlier studies raised the concern that bacteriuria may be associated with progression to symptomatic UTI and with deteriorating renal function in patients with diabetes, ${ }^{7,70}$ later studies found that diabetic women with ASB do not have an increased risk for a faster decline in renal function, ${ }^{71}$ and that there are no short- or long-term benefits from the treatment of ASB in diabetic women. ${ }^{72}$ A placebo-controlled, randomized prospective study of 105 women with diabetes mellitus found that during a mean follow-up period of 27 months, antibiotic treatment did not affect the rate of symptomatic UTI, pyelonephritis, or hospitalizations for UTI. ${ }^{72}$ A study from 2006 found that ASB by itself is not associated with an increased rate of progression to renal impairment or long term complications during 6 years of follow-up in patients with diabetes. ${ }^{71}$ Another study that followed diabetic women with ASB for up to 3 years found that bacteriuria persists

Table I First-line antibiotic treatment of urinary tract infection in patients with type 2 diabetes mellitus

\begin{tabular}{|c|c|c|c|c|c|}
\hline $\begin{array}{l}\text { Type of urinary tract } \\
\text { infection (UTI) }\end{array}$ & Sex & $\begin{array}{l}\text { Antibiotic } \\
\text { treatment }^{\mathrm{a}}\end{array}$ & Route & Dosage & $\begin{array}{l}\text { Duration of } \\
\text { treatment }\end{array}$ \\
\hline Asymptomatic bacteriuria & Men and women & None & & & \\
\hline \multirow[t]{3}{*}{ Acute cystitis } & Women & Nitrofurantoin & $\mathrm{PO}$ & $100 \mathrm{mg} \times 2-3 / \mathrm{d}$ & 5 days \\
\hline & & Fosfomycin & $\mathrm{PO}$ & $3 g$ & Single dose \\
\hline & & TMP-SMX & $\mathrm{PO}$ & $960 \mathrm{mg} \times 2 / \mathrm{d}$ & 3 days $^{b}$ \\
\hline Complicated lower UTI (including & Men and women & Ciprofloxacin & $\mathrm{PO}$ & $250-500 \mathrm{mg} \times 2 / \mathrm{d}$ & $7-14$ days $^{c}$ \\
\hline \multirow[t]{3}{*}{ catheter-associated UTI) } & & Ofloxacin & $\mathrm{PO}$ & $200 \mathrm{mg} \times 2 / \mathrm{d}$ & $7-14$ days $^{c}$ \\
\hline & & TMP-SMX & $\mathrm{PO}$ & $960 \mathrm{mg} \times 2 / \mathrm{d}^{\mathrm{b}}$ & $7-14$ days $^{c}$ \\
\hline & & Cefuroxime & $\mathrm{PO}$ & $500 \mathrm{mg} \times 2 / \mathrm{d}$ & $7-14$ days $^{c}$ \\
\hline \multirow[t]{7}{*}{ Uncomplicated pyelonephritis } & Women & Ciprofloxacin & $\mathrm{IV}^{\mathrm{e}}$ & $400 \mathrm{mg} \times 2 / \mathrm{d}$ & 7 days \\
\hline & & Ciprofloxacin & $\mathrm{PO}^{d}$ & $500 \mathrm{mg} \times 2 / \mathrm{d}$ & 7 days \\
\hline & & Ofloxacin & $\mathrm{IV}^{\mathrm{e}}$ & $400 \mathrm{mg} \times 2 / \mathrm{d}$ & 7 days \\
\hline & & Ofloxacin & $\mathrm{PO}^{d}$ & $400 \mathrm{mg} \times 2 / \mathrm{d}$ & 7 days \\
\hline & & Gentamicin & $\mathrm{IV}^{\mathrm{e}}$ & $5 \mathrm{mg} / \mathrm{kg} \times \mathrm{l} / \mathrm{d}$ & 7 days \\
\hline & & Cefuroxime & $\mathrm{IV}$ & $750 \mathrm{mg} \times 3 / \mathrm{d}$ & 10-14 days \\
\hline & & Cefuroxime & $\mathrm{PO}^{\mathrm{d}}$ & $500 \mathrm{mg} \times 2 / \mathrm{d}$ & $10-14$ days \\
\hline \multirow[t]{6}{*}{ Complicated pyelonephritis/urosepsis } & Men and women & Ciprofloxacin & $\mathrm{IV}^{\mathrm{e}}$ & $400 \mathrm{mg} \times 2 / \mathrm{d}$ & $10-14$ days $^{\mathrm{c}}$ \\
\hline & & Ofloxacin & $\mathrm{IV}^{\mathrm{e}}$ & $400 \mathrm{mg} \times 2 / \mathrm{d}$ & $10-14$ days $^{c}$ \\
\hline & & Gentamicin & $\mathrm{IV}^{\mathrm{e}}$ & $5 \mathrm{mg} / \mathrm{kg} \times \mathrm{I} / \mathrm{d}$ & $10-14$ days $^{c}$ \\
\hline & & Amikacin & $\mathrm{IV}^{\mathrm{e}}$ & $15 \mathrm{mg} / \mathrm{kg} \times \mathrm{I} / \mathrm{d}$ & $10-14$ days $^{c}$ \\
\hline & & Piperacillin-tazobactam & $\mathrm{IV}^{\mathrm{e}}$ & $4.5 \mathrm{~g} \times 3 / \mathrm{d}$ & $10-14$ days $^{c}$ \\
\hline & & Ertapenem & $\mathrm{IV}^{\mathrm{e}}$ & $\mathrm{Ig} \times \mathrm{I} / \mathrm{d}$ & $10-14$ days $^{c}$ \\
\hline
\end{tabular}

Notes: aAlways tailor antibiotic treatment according to urine culture results. 'Use empirically only when local resistance $<20 \%$. 'Length of treatment depends on severity of symptoms and patient response. ${ }^{\mathrm{d} A d m i n i s t e r}$ oral antibiotics to patients with mild to moderate symptoms that can tolerate oral therapy. ${ }^{\mathrm{e} S w i t c h}$ to oral therapy when patient is improving, clinically stable, and can tolerate oral therapy.

Abbreviations: TMP-SMX, trimethoprim-sulfamethoxazole; PO, per os (oral route); IV, intravenous; d, days; g, gram. 
or recurs in most women, is benign, and seldom permanently eradicable. ${ }^{73}$ All the above studies found that women with ASB received multiple courses of antibiotic therapy, which may result in increased antibiotic resistance.

Acute cystitis in women with good glucose control and without long-term diabetes complications may be managed as uncomplicated lower UTI, ${ }^{8}$ and treated empirically with one of the following: ${ }^{74}$ nitrofurantoin $100 \mathrm{mg}$ three times daily for 5 days, fosfomycin trometamol $3 \mathrm{~g}$ single dose, or trimethoprim-sulfamethoxazole $960 \mathrm{mg}$ twice daily for 3 days (can be administered empirically only if resistance prevalence is known to be less than $20 \%$ and medication was not used in previous 3 months). Quinolones and $\beta$-lactams are other, alternative second-line treatments. Treatment should be tailored according to culture results, if obtained.

Other cases of lower UTI in diabetic patients are mostly considered complicated lower UTI and should be treated with antibiotics. In patients with a chronic indwelling catheter, UTI prompts exchange of the urinary catheter. ${ }^{57}$ The wide variety of potential infecting organisms and increased likelihood of resistance make uniform recommendations for empirical therapy problematic. ${ }^{75}$ Whenever possible, antimicrobial therapy should be delayed pending results of urine culture and organism susceptibility, so specific therapy can be directed at the known pathogen. Therapeutic options include fluoroquinolones, trimethoprim-sulfamethoxazole, and $\beta$-lactames (Table 1).

Pyelonephritis in patients with type 2 diabetes may be treated with oral antibiotics in patients with mild-moderate symptoms,${ }^{74}$ with no alterations in gastrointestinal absorption, such as gastric emptying impairment or chronic diarrhea caused by diabetic neuropathy. However, diabetic patients with severe symptoms, hemodynamic instability, metabolic alterations, or symptoms that preclude administration of oral medication (nausea, vomiting) should be hospitalized for initial intravenous antibiotic therapy. ${ }^{8,74}$ Treatment with empiric antibiotics, using broad-spectrum cephalosporins, fluoroquinolones, aminoglycosides, piperacillin-tazobactam, or carbapenems should be initiated (Table 1). ${ }^{74,76}$ Patients presenting with severe sepsis or those known to harbor resistant uropathogens or that have received multiple antibiotic courses should receive broad-spectrum coverage, guided by recent urinary cultures. Treatment should be tailored when culture results are available.

Recommended duration of antibiotic treatment for UTI is depicted in Table 1, and is similar to that of non-diabetic patients. Though some argue that patients with diabetes mellitus should receive longer antibiotic treatment than patients without diabetes mellitus, ${ }^{77}$ randomized controlled trials are lacking.
Emphysematous pyelonephritis was historically treated by nephrectomy or open drainage, along with systemic antibiotics. In a more recent report, successful management with systemic antibiotics together with percutaneous catheter drainage of gas and purulent material, as well as relief of urinary tract obstruction, if present, has been described. ${ }^{78}$

The choice of antibiotics in patients with diabetes mellitus should also take into consideration possible drug interactions between antimicrobials and antidiabetics or antihypertensive agents, and impaired glucose homeostasis that may be caused by certain antibiotics. ${ }^{79}$ Dosage adjustment is required in diabetic patients with renal impairment for some antimicrobials agents. Due to their nephrotoxic effect, aminoglycosides should be used with caution in patients with renal failure, and nitrofurantoin should be avoided in patients with renal failure, due to drug accumulation that is associated with peripheral neuropathy. ${ }^{80}$

Management of recurrent episodes of UTI is similar to non-diabetic patients. ${ }^{8}$ In young women without diabetic complications, post-coital or daily low-dose antibiotic prophylaxis may be offered. ${ }^{74}$ In patients with renal failure, complex urologic abnormalities, or highly resistant bacteria, long-term antibiotic prophylaxis is less effective. ${ }^{8}$ In patients requiring catheterization due to incomplete bladder voiding, intermittent catheterization is preferred over a chronic indwelling catheter. ${ }^{57}$

\section{Conclusion}

UTI are common among patients with type 2 diabetes mellitus. In these patients, UTI are more severe, caused by more resistant pathogens, and is associated with worse outcomes than in patients without diabetes. Treatment should be offered only to symptomatic cases, as ASB is a common finding, and antibiotic treatment in such cases serves mostly to increase bacterial resistance. Treatment should be tailored according to severity of infection and culture results. Further studies are needed to improve the treatment of patients with type 2 diabetes and UTI.

\section{Disclosure}

The authors report no conflicts of interest in this work.

\section{References}

1. Patterson JE, Andriole VT. Bacterial urinary tract infections in diabetes. Infect Dis Clin North Am. 1997;11(3):735-750.

2. Joshi N, Caputo GM, Weitekamp MR, Karchmer AW. Infections in patients with diabetes mellitus. N Engl J Med. 1999;341(25):1906-1912.

3. Boyko EJ, Fihn SD, Scholes D, Abraham L, Monsey B. Risk of urinary tract infection and asymptomatic bacteriuria among diabetic and nondiabetic postmenopausal women. Am J Epidemiol. 2005;161(6):557-564.

4. Shah BR, Hux JE. Quantifying the risk of infectious diseases for people with diabetes. Diabetes Care. 2003;26(2):510-513. 
5. Delamaire M, Maugendre D, Moreno M, Le Goff MC, Allannic H, Genetet B. Impaired leucocyte functions in diabetic patients. Diabet Med. 1997;14(1):29-34.

6. Valerius NH, Eff C, Hansen NE, et al. Neutrophil and lymphocyte function in patients with diabetes mellitus. Acta Med Scand. 1982;211(6): 463-467.

7. Geerlings SE, Stolk RP, Camps MJ, et al. Asymptomatic bacteriuria can be considered a diabetic complication in women with diabetes mellitus. Adv Exp Med Biol. 2000;485:309-314.

8. Fünfstück R, Nicolle LE, Hanefeld M, Naber KG. Urinary tract infection in patients with diabetes mellitus. Clin Nephrol. 2012;77(1):40-48.

9. Truzzi JC, Almeida FM, Nunes EC, Sadi MV. Residual urinary volume and urinary tract infection - when are they linked? J Urol. 2008;180(1): 182-185.

10. Hosking DJ, Bennett T, Hampton JR. Diabetic autonomic neuropathy. Diabetes.1978;27(10):1043-1055.

11. Brown JS, Wessells H, Chancellor MB, et al. Urologic complications of diabetes. Diabetes Care. 2005;28(1):177-185.

12. Kofteridis DP, Papadimitraki E, Mantadakis E, et al. Effect of diabetes mellitus on the clinical and microbiological features of hospitalized elderly patients with acute pyelonephritis. J Am Geriatr Soc. 2009; 57(11):2125-2128.

13. Mnif MF, Kamoun M, Kacem FH, et al. Complicated urinary tract infections associated with diabetes mellitus: pathogenesis, diagnosis and management. Indian J Endocrinol Metab. 2013;17(3):442-445.

14. Datta P, Rani H, Chauhan R, Gombar S, Chander J. Health-careassociated infections: risk factors and epidemiology from an intensive care unit in Northern India. Indian J Anaesth. 2014;58(1):30-35.

15. Lee JH, Kim SW, Yoon BI, Ha US, Sohn DW, Cho YH. Factors that affect nosocomial catheter-associated urinary tract infection in intensive care units: 2-year experience at a single center. Korean J Urol. 2013; 54(1):59-65.

16. Lim JH, Cho JH, Lee JH, et al. Risk factors for recurrent urinary tract infection in kidney transplant recipients. Transplant Proc. 2013;45(4): 1584-1589.

17. Inns T, Millership S, Teare L, Rice W, Reacher M. Service evaluation of selected risk factors for extended-spectrum beta-lactamase Escherichia coli urinary tract infections: a case-control study. $J$ Hosp Infect. 2014;88(2):116-119.

18. Wu YH, Chen PL, Hung YP, Ko WC. Risk factors and clinical impact of levofloxacin or cefazolin nonsusceptibility or ESBL production among uropathogens in adults with community-onset urinary tract infections. J Microbiol Immunol Infect. 2014;47(3):197-203.

19. Schechner V, Kotlovsky T, Kazma M, et al. Asymptomatic rectal carriage of blaKPC producing carbapenem-resistant Enterobacteriaceae: who is prone to become clinically infected? Clin Microbiol Infect. 2013;19(5):451-456.

20. Papadimitriou-Olivgeris M, Drougka E, Fligou F, et al. Risk factors for enterococcal infection and colonization by vancomycin-resistant enterococci in critically ill patients. Infection. 2014;42(6):1013-1022.

21. Sobel JD, Fisher JF, Kauffman CA, Newman CA. Candida urinary tract infections - epidemiology. Clin Infect Dis. 2011;52(Suppl 6): S433-S436.

22. Yu S, Fu AZ, Qiu Y, et al. Disease burden of urinary tract infections among type 2 diabetes mellitus patients in the US. $J$ Diabetes Complications. 2014;28(5):621-626.

23. Venmans LM, Hak E, Gorter KJ, Rutten GE. Incidence and antibiotic prescription rates for common infections in patients with diabetes in primary care over the years 1995 to 2003. Int J Infect Dis. 2009;13(6): e344-e351.

24. Hirji I, Guo Z, Andersson SW, Hammar N, Gomez-Caminero A. Incidence of urinary tract infection among patients with type 2 diabetes in the UK General Practice Research Database (GPRD). $J$ Diabetes Complications. 2012;26(6):513-516.

25. Hammar N, Farahmand B, Gran M, Joelson S, Andersson SW. Incidence of urinary tract infection in patients with type 2 diabetes. Experience from adverse event reporting in clinical trials. Pharmacoepidemiol Drug Saf. 2010;19(12):1287-1292.
26. Fu AZ, Iglay K, Qiu Y, Engel S, Shankar R, Brodovicz K. Risk characterization for urinary tract infections in subjects with newly diagnosed type 2 diabetes. J Diabetes Complications. 2014;28(6):805-810.

27. Colgan R, Nicolle LE, McGlone A, Hooton TM. Asymptomatic bacteriuria in adults. Am Fam Physician. 2006;74(6):985-990.

28. Nicolle LE. Asymptomatic bacteriuria. Curr Opin Infect Dis. 2014; 27(1):90-96

29. Zhanel GG, Nicolle LE, Harding GK. Prevalence of asymptomatic bacteriuria and associated host factors in women with diabetes mellitus. The Manitoba Diabetic Urinary Infection Study Group. Clin Infect Dis. 1995;21(2):316-322.

30. Schneeberger C, Kazemier BM, Geerlings SE. Asymptomatic bacteriuria and urinary tract infections in special patient groups: women with diabetes mellitus and pregnant women. Curr Opin Infect Dis. 2014;27(1):108-114.

31. Renko M, Tapanainen P, Tossavainen P, Pokka T, Uhari M. Metaanalysis of the significance of asymptomatic bacteriuria in diabetes. Diabetes Care. 2011;34(1):230-235.

32. Aswani SM, Chandrashekar U, Shivashankara K, Pruthvi B. Clinical profile of urinary tract infections in diabetics and non-diabetics. Australas Med J. 2014;7(1):29-34.

33. Scholes D, Hooton TM, Roberts PL, Gupta K, Stapleton AE, Stamm WE. Risk factors associated with acute pyelonephritis in healthy women. Ann Intern Med. 2005;142(1):20-27.

34. Nicolle LE, Friesen D, Harding GK, Roos LL. Hospitalization for acute pyelonephritis in Manitoba, Canada, during the period from 1989 to 1992; impact of diabetes, pregnancy, and aboriginal origin. Clin Infect Dis. 1996;22(6):1051-1056.

35. Benfield T, Jensen JS, Nordestgaard BG. Influence of diabetes and hyperglycaemia on infectious disease hospitalisation and outcome. Diabetologia. 2007;50(3):549-554.

36. Bilo HJ. [Susceptibility to infection in patients with diabetes mellitus]. Ned Tijdschr Geneeskd. 2006;150(10):533-534. Dutch.

37. Wen SC, Juan YS, Wang CJ, et al. Emphysematous prostatic abscess: case series study and review. Int J Infect Dis. 2012;16(5): e344-e349.

38. Chen SL, Jackson SL, Boyko EJ. Diabetes mellitus and urinary tract infection: epidemiology, pathogenesis and proposed studies in animal models. $J$ Urol. 2009;182(6 Suppl):S51-S56.

39. Wang $\mathrm{MC}$, Tseng $\mathrm{CC}, \mathrm{Wu} \mathrm{AB}$, et al. Bacterial characteristics and glycemic control in diabetic patients with Escherichia coli urinary tract infection. J Microbiol Immunol Infect. 2013;46(1):24-29.

40. Boyko EJ, Fihn SD, Scholes D, Chen CL, Normand EH, Yarbro P. Diabetes and the risk of acute urinary tract infection among postmenopausal women. Diabetes Care. 2002;25(10):1778-1783.

41. Soo Park B, Lee SJ, Wha Kim Y, Sik Huh J, Il Kim J, Chang SG. Outcome of nephrectomy and kidney-preserving procedures for the treatment of emphysematous pyelonephritis. Scand J Urol Nephrol. 2006;40(4):332-338.

42. Geerlings SE, Brouwer EC, Van Kessel KC, Gaastra W, Stolk RP, Hoepelman AI. Cytokine secretion is impaired in women with diabetes mellitus. Eur J Clin Invest. 2000;30(11):995-1001.

43. Kaplan SA, Te AE, Blaivas JG. Urodynamic findings in patients with diabetic cystopathy. J Urol. 1995;153(2):342-344.

44. Frimodt-Møller C. Diabetic cystopathy: epidemiology and related disorders. Ann Intern Med. 1980;92(2 Pt 2):318-321.

45. Al-Rubeaan KA, Moharram O, Al-Naqeb D, Hassan A, Rafiullah MR. Prevalence of urinary tract infection and risk factors among Saudi patients with diabetes. World J Urol. 2013;31(3):573-578.

46. Nicolle LE, Capuano G, Fung A, Usiskin K. Urinary tract infection in randomized phase III studies of canagliflozin, a sodium glucose co-transporter 2 inhibitor. Postgrad Med. 2014;126(1): $7-17$.

47. Yang XP, Lai D, Zhong XY, Shen HP, Huang YL. Efficacy and safety of canagliflozin in subjects with type 2 diabetes: systematic review and meta-analysis. Eur J Clin Pharmacol. 2014;70(10):1149-1158. 
48. Ptaszynska A, Johnsson KM, Parikh SJ, de Bruin TW, Apanovitch AM, List JF. Safety profile of dapagliflozin for type 2 diabetes: pooled analysis of clinical studies for overall safety and rare events. Drug Saf. 2014;37(10):815-829.

49. Geerlings SE, Meiland R, van Lith EC, Brouwer EC, Gaastra W, Hoepelman AI. Adherence of type 1-fimbriated Escherichia coli to uroepithelial cells: more in diabetic women than in control subjects. Diabetes Care. 2002;25(8):1405-1409.

50. Colodner R, Rock W, Chazan B, et al. Risk factors for the development of extended-spectrum beta-lactamase-producing bacteria in nonhospitalized patients. Eur J Clin Microbiol Infect Dis. 2004;23(3):163-167.

51. Kim Y, Wie SH, Chang UI, et al. Comparison of the clinical characteristics of diabetic and non-diabetic women with community-acquired acute pyelonephritis: a multicenter study. J Infect. 2014;69(3):244-251.

52. Carton JA, Maradona JA, Nuño FJ, Fernandez-Alvarez R, PérezGonzalez F, Asensi V. Diabetes mellitus and bacteraemia: a comparative study between diabetic and non-diabetic patients. Eur J Med. 1992;1(5): 281-287.

53. Stamm WE. Measurement of pyuria and its relation to bacteriuria. Am J Med.1983;75(1B):53-58.

54. Little P, Turner S, Rumsby K, et al. Dipsticks and diagnostic algorithms in urinary tract infection: development and validation, randomised trial, economic analysis, observational cohort and qualitative study. Health Technol Assess. 2009;13(19):iii-iv, ix-xi, 1-73.

55. Giesen LG, Cousins G, Dimitrov BD, van de Laar FA, Fahey T. Predicting acute uncomplicated urinary tract infection in women: a systematic review of the diagnostic accuracy of symptoms and signs. BMC Fam Pract. 2010;11:78.

56. Bennett JE, Doli R, Blaser MJ. Mandell, Douglas, and Bennetts Principles and Practice of Infectious Diseases. 8th ed. Elsevier Inc. 2015.

57. Hooton TM, Bradley SF, Cardenas DD, et al; Infectious Diseases Society of America. Diagnosis, prevention, and treatment of catheter-associated urinary tract infection in adults: 2009 International Clinical Practice Guidelines from the Infectious Diseases Society of America. Clin Infect Dis. 2010;50(5):625-663.

58. Kunin CM, Chin QF, Chambers S. Indwelling urinary catheters in the elderly: relation of "catheter life" to formation of encrustations in patients with and without blocked catheters. Am J Med. 1987;82: 405-411.

59. Kass EH. Asymptomatic infections of the urinary tract. Trans Assoc Am Physicians. 1956;69:56-64.

60. Kunin CM, White LV, Hua TH. A reassessment of the importance of "low-count" bacteriuria in young women with acute urinary symptoms. Ann Intern Med. 1993;119(6):454-460.

61. Rubin RH, Shapiro ED, Andriole VT, Davis RJ, Stamm WE. Evaluation of new anti-infective drugs for the treatment of urinary tract infection. Infectious Diseases Society of America and the Food and Drug Administration. Clin Infect Dis. 1992;15 Suppl 1:S216-S227.

62. Stark RP, Maki DG. Bacteriuria in the catheterized patient. What quantitative level of bacteriuria is relevant? NEngl J Med. 1984;311(9): $560-564$.

63. Raz R. Asymptomatic bacteriuria. Clinical significance and management. Int J Antimicrob Agents. 2003;22 Suppl 2:45-47.

64. Zhanel GG, Harding GK, Nicolle LE. Asymptomatic bacteriuria in patients with diabetes mellitus. Rev Infect Dis. 1991;13(1):150-154.
65. Pertel PE, Haverstock D. Risk factors for a poor outcome after therapy for acute pyelonephritis. BJU Int. 2006;98(1):141-147.

66. Wie SH, Ki M, Kim J, et al. Clinical characteristics predicting early clinical failure after $72 \mathrm{~h}$ of antibiotic treatment in women with community-onset acute pyelonephritis: a prospective multicentre study. Clin Microbiol Infect. 2014;20(10):721-729.

67. Gorter KJ, Hak E, Zuithoff NP, Hoepelman AI, Rutten GE. Risk of recurrent acute lower urinary tract infections and prescription pattern of antibiotics in women with and without diabetes in primary care. Fam Pract. 2010;27(4):379-385.

68. Thomas AA, Lane BR, Thomas AZ, Remer EM, Campbell SC, Shoskes DA. Emphysematous cystitis: a review of 135 cases. BJU Int. 2007;100(1):17-20.

69. Nicolle LE, Bradley S, Colgan R, Rice JC, Schaeffer A, Hooton TM; Infectious Diseases Society of America; American Society of ephrology; American Geriatric Society. Infectious Diseases Society of America guidelines for the diagnosis and treatment of asymptomatic bacteriuria in adults. Clin Infect Dis. 2005;40(5):643-654.

70. Batalla MA, Balodimos MC, Bradley RF. Bacteriuria in diabetes mellitus. Diabetologia. 1971;7(5):297-301.

71. Meiland R, Geerlings SE, Stolk RP, Netten PM, Schneeberger PM, Hoepelman AI. Asymptomatic bacteriuria in women with diabetes mellitus: effect on renal function after 6 years of follow-up. Arch Intern Med. 2006;166(20):2222-2227.

72. Nicolle LE, Zhanel GG, Harding GK. Microbiological outcomes in women with diabetes and untreated asymptomatic bacteriuria. World J Urol. 2006;24(1):61-65.

73. Harding GK, Zhanel GG, Nicolle LE, Cheang M; Manitoba Diabetes Urinary Tract Infection Study Group. Antimicrobial treatment in diabetic women with asymptomatic bacteriuria. $N$ Engl J Med. 2002; 347(20):1576-1583.

74. Gupta K, Hooton TM, Naber KG, et al; Infectious Diseases Society of America; European Society for Microbiology and Infectious Diseases. International clinical practice guidelines for the treatment of acute uncomplicated cystitis and pyelonephritis in women: A 2010 update by the Infectious Diseases Society of America and the European Society for Microbiology and Infectious Diseases. Clin Infect Dis. 2011;52(5):e103-e120.

75. Dielubanza EJ, Mazur DJ, Schaeffer AJ. Management of non-catheterassociated complicated urinary tract infection. Infect Dis Clin North Am. 2014;28(1):121-134.

76. Nicolle LE. Uncomplicated urinary tract infection in adults including uncomplicated pyelonephritis. Urol Clin North Am. 2008;35(1):1-12.

77. Geerlings SE. Urinary tract infections in patients with diabetes mellitus: epidemiology, pathogenesis and treatment. Int J Antimicrob Agents. 2008;31 Suppl 1:S54-7.

78. Lin WR, Chen M, Hsu JM, Wang CH. Emphysematous pyelonephritis: patient characteristics and management approach. Urol Int. 2014;93(1): 29-33.

79. Chan JC, Cockram CS, Critchley JA. Drug-induced disorders of glucose metabolism. Mechanisms and management. Drug Saf. 1996;15(2): $135-157$.

80. Munar MY, Singh H. Drug dosing adjustments in patients with chronic kidney disease. Am Fam Physician. 2007;75(10):1487-1496.

Diabetes, Metabolic Syndrome and Obesity: Targets and Therapy

\section{Publish your work in this journal}

Diabetes, Metabolic Syndrome and Obesity: Targets and Therapy is an international, peer-reviewed open-access journal committed to the rapid publication of the latest laboratory and clinical findings in the fields of diabetes, metabolic syndrome and obesity research. Original research, review, case reports, hypothesis formation, expert opinion and commentaries are all considered for publication. The manuscript management system is completely online and includes a very quick and fair peer-review system, which is all easy to use. Visit http://www.dovepress.com/testimonials.php to read real quotes from published authors. 